\title{
Investigations by Raman microscopy, ESEM and FTIR-ATR of wall paintings from Qasr el-Ghuieta temple, Kharga Oasis, Egypt
}

\author{
Hussein H Marey Mahmoud
}

\begin{abstract}
In the present work, a multi-analytical approach was used to analyze samples collected from the wall paintings of Qasr el-Ghuieta temple, Kharga Oasis, Egypt. The temple is dating back to the 27th dynasty (525-404 BC) and was completed during the Ptolemaic period. The samples were analyzed by optical microscopy (OM), environmental scanning electron microscopy (ESEM) coupled with an energy dispersive X-ray analysis system (EDX), Raman microscopy and Fourier transform infrared-attenuated total reflectance spectroscopy (FTIR-ATR). The chromatic palette used in the temple was identified as Egyptian blue (cuprorivaite), red ochre (haematite), yellow ochre (goethite) and carbon black (from a vegetable origin). The green pigment was identified as green earth, however, a green tonality was also obtained through a mixture of Egyptian blue and yellow ochre, and in some samples, carbon black was also found. Several amounts of anatase and carbon black were found in the red and yellow ochre samples, respectively. The analysis showed that the preparation layer is almost made of pure gypsum, while the plaster layer based mainly on gypsum with variable amounts of quartz, calcite and clay minerals. The results showed that the painting materials and techniques used in the temple are almost the same of those used in the Egyptian temples with respect to the stratigraphy of paint layers, chromatic palette and the painting technique employed.
\end{abstract}

Keywords: Qasr el-Ghuieta temple, Kharga Oasis, Wall paintings, ESEM-EDX, Raman microscopy, FTIR-ATR

\section{Archaeological background Kharga Oasis}

Kharga Oasis is located to the west of the Nile valley, about $550 \mathrm{~km}$ to the South of Cairo. Kharga, is the largest oasis of the Libyan desert and consists of a depression (about $160 \mathrm{~km}$ long and 20-80 km wide) (Bliss and Osing, 1985). Kharga Oasis was an important transit point for the desert caravans since the 12th dynasty (c. 1786-1665 BC) [1]. The largest and best preserved site at Kharga Oasis is the temple of Hibis from the Persian period (c. 660-330 $\mathrm{BC})$, located about two kilometres to the north of the modern city of Kharga. During the Christian period, some of the old temples and forts in the oasis were converted to churches and monasteries [2].

Correspondence: marai79@hotmail.com

Department of Conservation, Faculty of Archaeology, Cairo University, 12613 Giza, Egypt

Chemistry Central

\section{Qasr el-Ghuieta temple}

Qasr el-Ghuieta temple is located about $18 \mathrm{~km}$ in the south of Kharga city. The temple is dating back to the 27th dynasty (525-404 BC) and was completed during the Ptolemaic period. In 1972, A. Fakhry cleared the temple and some buildings in front of the temple were found. These buildings show extensive damage from fire and the destruction probably dates to the time of the Blemmyes in the 5th century AD [3]. In more recent years, a series of excavations inside and outside the walls of the temple were undertaken. The work outside has focused on two areas; the first has been around the south east corner of the fort (mostly Roman period remains). A variety of houses and related structures were unearthed with a few Greek ostraca, a Demotic ostrakon, and pottery. The second area outside the walls was the "quay" structure directly east of the gate. Some authors suggest that Qasr el-Ghueita temple in its present form dates back to the reigns of Darius I and Ptolemy III, with additional texts and scenes added by Ptolemy IV Philopator and Ptolemy 
IX Soter II. The work of the Theban Desert Road Survey (by Yale Egyptological Institute in Egypt [4]) at el-Ghueita temple has revealed that the central rear chamber of the temple, decorated in both painted plaster and raised relief carving under Darius I, incorporates within it a small, formerly freestanding sandstone shrine of some date prior to the Twenty-Seventh Dynasty. In general, the temple comprises four sections: a forecourt, a hypostyle hall with four columns, a vestibule, and three inner chambers, of which only the centre room bears decoration. On the façade and jambs of the entrance portal to this central sanctuary are scenes and inscriptions of Ptolemy III Euergetes I in a sunken relief [5]. Inscriptions on the door jambs of the sanctuary and forecourt, state that Ptolemy III Euergetes I built both the columned hall and the temple forecourt. The temple, dedicated to the Theban triad of Amun, Mut and Khonsu, is entered through a sandstone gate on the southern side of the enclosure walls. Figure 1 shows a general view of the temple, some wall decorations and detailed plan of the temple.

\section{Selection of the analytical techniques}

The analysis of painting materials is considered an integral part of any pre-restoration research. In case of wall paintings, paint analysis usually begins with visual observation, for the purpose of locating representative areas for analysis. The optical microscopy helps in gathering information about the thickness and sequence of paint layers, colour and texture of those layers [6]. In order to study the morphology and chemical composition of the samples, scanning electron microscopy is usually used and the elemental microanalysis by SEM-EDX is always a valuable preliminary orientation [7]. Raman spectroscopy is a micro-analytical technique achieved several advantages in analysis of ancient painting materials. It has been successfully applied to study ancient Egyptian pigments and wall paintings [8-12]. This technique is nondestructive because little sample preparation is required or no sampling in case of micro-Raman [13]. Raman analysis is particularly suitable for the identification of pigments in complex matrixes and inorganic pigments in artworks [14-17]. The objectives in Raman microscopy allow the laser radiation to be focused on a 1-3 $\mu \mathrm{m}$ spot typically in the visible region (in the infrared, the spot size is $10 \mu \mathrm{m}$ and over), which is particularly useful for the identification of specific components in heterogeneous mixtures. In Fourier transform infrared-attenuated total reflectance spectroscopy (FTIR-ATR), the sample is in direct contact with the crystal that allows the infrared radiation to penetrate through the sample many times. This is due to the crystal having a high Refractive Index causing

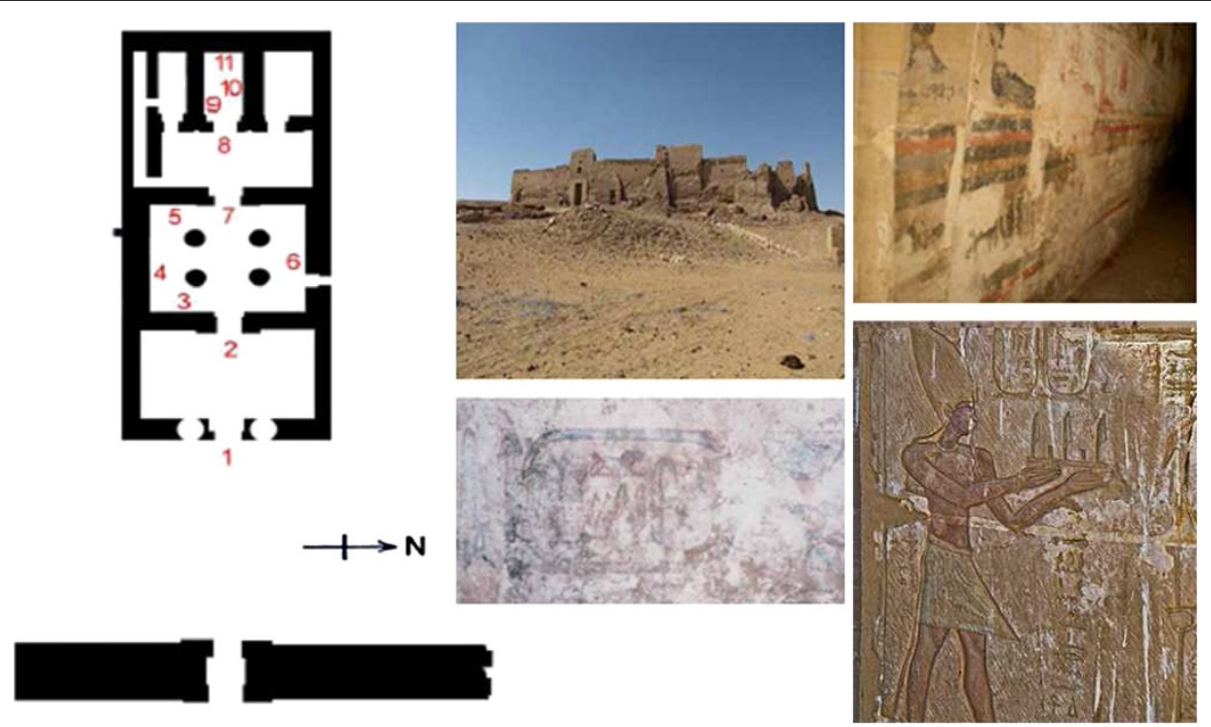

Figure 1 General view of the temple, some wall decorations and detailed plan of the temple. (1). Entrance of the temple; (2). Facade and entrance to the pillared hall; (3). Inscriptions of Ptolemy III, Amun Re, Khonsu, and Mut; (4). On the south wall, scenes of Ptolemy III, Montu, Horus and Hathor; (5). In the west wall, Ptolemy IV Filopator followed by his wife, Maat, Amun-Re seated on the throne and Amonet standing behind him; (6). In the north wall, scenes of Ptolemy X Soter II making offerings to the Theban triad of Amun-Re, Mut and Khonsu; (7). On the outside edge of the door to the lobby, Ptolemy III and Berenice before the Theban triad of Amun-Re; (8). At the entrance of the shrine, scenes of Ptolemy III, Berenice II immediately before the Theban triad; (9). Sanctuary (Dynasty XXVII), on the side walls of the sanctuary (9)-(10) are the remains of two similar scenes, and only painted in pretty poor condition showing left, and Darius offering an image of Maat, in front of a row of deities and right offering two vessels in a row deities other than the above, and on the back wall of the sanctuary (11), made in relief, but it destroyed in some places to the right, you can see King Darius I in offering an image of Maat, the triad: Amun, Mut and Khonsu. 
the infrared radiation to be bounced back many times. The use of ATR eliminates, in many cases, the need for sample preparation or at least simplifies the procedures.

\section{Research aims}

In general, many studies have been devoted to characterize materials dating back to the Roman age from different sites around the world, some of these materials are pigments [18-28], mortars [29-31], and plasters [32]. In contract of this, few studies were undertaken to study materials from Ptolemaic and Roman monuments in Egypt [33-38]. For this, the mean aim of the present work was to study pigment and plaster samples collected from the temple of Qasr el-Ghuieta, Kharga Oasis, Egypt using different analytical techniques. The obtained data will allow a comparison between wall paintings from the late period and Ptolemaic age with those from the Pharaonic age.

\section{Material and methods Samples}

As a result of the deterioration factors affecting the site (mainly salt weathering), the wall decorations are suffering from exfoliation and several detachments. A total number of eleven samples (with approximate dimensions $1 \times 1.5$ to $2 \times 2.5 \mathrm{~cm}$ ) were carefully chosen for analysis. Also, some grains (a few milligrams) from the well preserved decorations were carefully scraped off the painted walls with a metallic scalpel. In order to get information on the startigraphy of the paint layers (mainly the blue paint layers due to the size of samples), cross-sections were prepared prior to analysis by optical microscopy and ESEM, the samples were embedded in Epoxy resin (EpoFix), cross-sectioned using variable silicon carbide papers and DP-lubricant blue for fine and cool polishing, and mounted on glass slides.

\section{Optical microscopy}

Preliminary observations on the samples were performed using an Olympus SZ-40 stereomicroscope (10 and 20x objectives) equipped with an Olympus DP10 digital camera. Optical observations on the cross-sections were carried out using an Olympus BX60 in reflection mode (with optical magnifications $50 \times$ to $500 \times$ ) equipped with a JVC KY-F1030 digital camera. The optical images were captured in the reflected light which helped in identifying the structure of the paint layers and the colour of certain individual pigment grains. The prepared thin-sections of the plaster samples were examined by a Nikon Eclipse E600 microscope with photographic PixeLINK PL-A623 digital camera.

\section{ESEM and micro X-ray analysis}

The microstructure and microanalysis of the studied samples were analyzed by environmental scanning electron microscope model Philips XL-30 ESEM. This equipment is a field-emission source, offering a wide range of operating conditions, in which specimens can be examined with high chamber pressure environment. The X-ray microanalysis was carried out using an EDX detector (in a EDAX, Apollo SDD 10) with $20 \mathrm{Kv}$ accelerating voltage and pressure of 3.0 Torr. EDX data acquisition was obtained through GENESIS 6.x software. Microanalysis of single pigment grains down to $1 \mu \mathrm{m}$, as well as of the matrix and the total average of the paint layer were performed. Also, some polished cross-sections were investigated.

\section{Raman microspectroscopy}

Raman spectra were recorded using a Renishaw InVia Raman spectrometer in the near infrared excitation line $(785 \mathrm{~nm})$ of a diode laser source. The instrument is equipped with Peltier cooled charge coupled device (CCD 576x400 pixels). A Leica DMLM microscope with a XYZ motorized stage with 200 and 500 magnification objectives was equipped to the Raman spectrometer which helped in providing a sample irradiation diameter of up to $1 \mu \mathrm{m}$. A polarized unit system is mounted onto the microscope which offers a clear view of the area under investigation, necessary for positioning the beam on individual pigment particles. The lower laser powers (up to $0.5 \mathrm{~mW}$ ) were used to avoid inducing thermal changes to the mineralogy of the iron oxide minerals. Typical exposure time of the CCD was 20s per scan, while normally 5 up to 20 accumulations were co-added to produce the final spectrum in order to improve the signal-to-noise ratios.

\section{FTIR-ATR spectroscopy}

FTIR-ATR spectra were collected on a Perkin Elmer spectrometer 400 equipped with an ATR (attenuated total reflectance) detector using a diamond cell in the wavelength range of $4000-650 \mathrm{~cm}^{-1}$, at a spectral resolution of $4 \mathrm{~cm}^{-1}$ over 32 scans. A background of the clean diamond cell was performed for each analysis undertaken. The diamond cell requires only minute amounts of sample material. Also, spectra were recorded by contacting the ATR crystal directly onto the polished surfaces of the mounted cross sections.

\section{Results}

Table 1 summarizes the results obtained from different analytical techniques employed to study the samples.

\section{Visual observations}

Figure 2 shows microscopic images (under the reflected light) obtained on the blue and green paint layers. The microscopic examination of the blue paint layer shows deep and light blue crystals spread within a transparent matrix (Figure 2a). The green paint area shows various 
Table 1 Summary of the results obtained from different analytical techniques employed to study the samples

\begin{tabular}{|c|c|c|c|c|c|}
\hline Sample & Colour & Optical observation & ESEM-EDAX & $\mu$-Raman & FTIR-ATR \\
\hline \multirow[t]{4}{*}{ Painted fragment } & \multirow[t]{4}{*}{ Dark blue } & - Thickness $=150-250 \mu \mathrm{m}$. & \multirow[t]{4}{*}{$\mathrm{Si}, \mathrm{Ca}, \mathrm{Cu}, \mathrm{S}, \mathrm{Fe}, \mathrm{Al}, \mathrm{Mg}$} & \multirow[t]{4}{*}{ * } & Cuprorivaite \\
\hline & & \multirow{3}{*}{$\begin{array}{l}\text { - Under reflected light: coarse heterogonous crystals } \\
\text { (30 } \mathrm{mm} \text { in length) with dark blue colour are observed. }\end{array}$} & & & Quartz \\
\hline & & & & & Gypsum \\
\hline & & & & & Calcite \\
\hline \multirow[t]{3}{*}{ Pigment } & \multirow[t]{3}{*}{ Light blue } & - Thickness $=100-200 \mu \mathrm{m}$. & \multirow[t]{3}{*}{$\mathrm{Si}, \mathrm{Ca}, \mathrm{Cu}, \mathrm{S}, \mathrm{Fe}, \mathrm{Al}, \mathrm{Mg}$} & \multirow[t]{3}{*}{ * } & Cuprorivaite \\
\hline & & \multirow{2}{*}{$\begin{array}{l}\text { - It appears as pale blue probably due to the white } \\
\text { binding medium (gypsum). }\end{array}$} & & & Quartz \\
\hline & & & & & Gypsum \\
\hline \multirow[t]{4}{*}{ Pigment } & \multirow[t]{4}{*}{ Green } & - Thickness $=150-200 \mu \mathrm{m}$ & \multirow[t]{4}{*}{$\mathrm{Si}, \mathrm{Ca}, \mathrm{Cu}, \mathrm{S}, \mathrm{Fe}, \mathrm{Al}, \mathrm{Mg}$} & \multirow[t]{4}{*}{ * } & Cuprorivaite \\
\hline & & \multirow{3}{*}{$\begin{array}{l}\text { - Dark blue and yellow grains are observed, black grains } \\
\text { can be seen in some areas. }\end{array}$} & & & Quartz \\
\hline & & & & & Goethite \\
\hline & & & & & Kaolinite \\
\hline \multirow[t]{5}{*}{ Painted fragment } & \multirow[t]{5}{*}{ Dark red } & - Thickness $=50-70 \mu \mathrm{m}$ & \multirow[t]{5}{*}{$\mathrm{Si}, \mathrm{Ca}, \mathrm{S}, \mathrm{Fe}, \mathrm{C}, \mathrm{Al}, \mathrm{K}, \mathrm{Mg}$} & Haematite & Haematite \\
\hline & & \multirow{4}{*}{$\begin{array}{l}\text { - Several voids are spread on the surface and black } \\
\text { grains are found. }\end{array}$} & & \multirow[t]{4}{*}{ Anatase } & Quartz \\
\hline & & & & & Carbon \\
\hline & & & & & Kaolinite \\
\hline & & & & & Gypsum \\
\hline \multirow[t]{4}{*}{ Paint flake } & \multirow[t]{4}{*}{ Yellow } & - Thickness $=30 \mu \mathrm{m}$. & \multirow[t]{4}{*}{$\mathrm{Si}, \mathrm{Ca}, \mathrm{S}, \mathrm{Fe}, \mathrm{Al}, \mathrm{K}, \mathrm{Mg}$} & Goethite & Goethite \\
\hline & & \multirow{3}{*}{$\begin{array}{l}\text { - The surface is slightly compact with red and black } \\
\text { grains within the paint layer. }\end{array}$} & & \multirow[t]{3}{*}{ Carbon black } & Gypsum \\
\hline & & & & & Quartz \\
\hline & & & & & Kaolinite \\
\hline \multirow[t]{3}{*}{ Painted fragment } & \multirow[t]{3}{*}{ Black } & \multirow[t]{3}{*}{ - Thickness = 30-70 $\mu \mathrm{m}$. } & \multirow[t]{3}{*}{ C, Si, Fe, Ca, S, Cl, Na, Al, Mg, K, Ti } & Carbon black & Carbon \\
\hline & & & & \multirow[t]{2}{*}{ Quartz } & Quartz \\
\hline & & & & & Gypsum \\
\hline \multirow[t]{2}{*}{ Preparation layer } & White & - Thickness $=100-200 \mu \mathrm{m}$ & $\mathbf{S}, \mathbf{C a}, \mathrm{Si}, \mathrm{Al}, \mathrm{Mg}$ & Gypsum & Gypsum \\
\hline & & & & & Quartz \\
\hline Plaster layer & Creamy & - Thickness = 2-4 mm. & $\mathrm{S}, \mathrm{Ca}, \mathrm{Si}, \mathrm{Al}$ & Gypsum & Gypsum \\
\hline & & - The sample filled with angular particles. & & Quartz & Anhydrite \\
\hline & & & & Calcite & Quartz \\
\hline & & & & & Calcite \\
\hline
\end{tabular}

*Blue and green pigment samples showed strong fluoresce when excited at $785 \mathrm{~nm}$.

Bold element indicates correlation with the main pigment mineral.
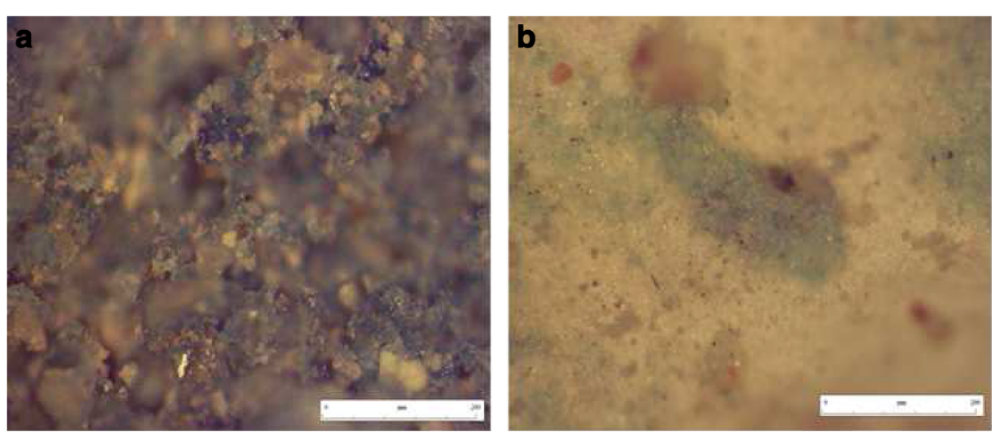

Figure 2 Optical photomicrographs of: (a) blue pigment sample (microscope objective 50× magnification, under reflected light), (b) yellow pigment sample (microscope objective 20x magnification, under reflected light). 
shades with blue and yellow-orange particles scattered in the matrix. The green particles are pale, rounded and translucent with some exhibiting of grainy texture (Figure 2b). The optical examination of the yellow pictorial layer shows small and rounded grains of the pigment and the hue is affected by impurities found in the layer. Also, the examination shows black and red grains (up to $30 \mu \mathrm{m}$ length) scattered on the surface. The red paint layer shows deep brown to reddish hues with dark particles in the layer.

\section{Microstructure and microanalysis (ESEM-EDX)}

Figure 3 shows an ESEM image and element distribution map obtained on polished cross-section of the blue paint layer. The ESEM image showed the slightly thick paint layer with heterogeneity in its components. The major elements distributed in the section were silicon, calcium and copper, corresponding to the mineral "cuprorivaite" $\left(\mathrm{CaCuSi}_{4} \mathrm{O}_{10}\right)$, a synthetic pigment first prepared in ancient Egypt in the $3^{\text {rd }}$ millennium $\mathrm{BC}$. In Figure 4, the ESEM images obtained on the outer surfaces of the paint layers are present. The ESEM image obtained on the outer surface of the green pigment sample (Figure 4a) shows an idealized light grey crystal of cuprorivaite. The spot microanalysis obtained on individual crystal in the sample indicates that the predominant elements are silicon, calcium and copper. Other elements detected were of aluminium and potassium with high concentration of iron. This confirms that Egyptian blue was mixed with iron oxides to obtain a green tone. In Figure $4 \mathrm{~b}$, fine grains with slightly coarse grains are dispersed within the matrix. The EDX microanalysis showed that calcium, silicon, aluminium, magnesium, potassium and iron are the main elements in the sample. The absence of copper in the green pigment sample excludes the use of copperbased compounds and confirms that green earth (Terre
Verte) was used as the green pigment. ESEM investigation of the red paint layer (Figure 4c) shows the heavy weathered pigmented layer due to salt weathering. The fine granular particles of the ochre can be observed. The EDX microanalysis of the sample showed a high concentration of silicon together with a strong peak of iron indicating the existence of iron oxide as the possible material producing the red colour. Calcium, sulphur, aluminium, sodium, potassium were also detected. For the yellow pigment, the ESEM image (Figure 4d) shows slightly fine grains of the pigment material. Black grains centred in the image are clearly noticeable. EDX microanalysis obtained on the sample shows the presence of iron together with minor amounts of aluminium and silicon as in the red pigment sample. This could be due to the existence an aluminosilicate material (e.g. clay minerals which could be primary accessory minerals in ochre pigments). Spot microanalysis of the black grains in the sample showed high concentration of carbon suggests the presence of carbon black probably added to produce special hues or tonalities. The investigation of the black pigment (Figure 4e) shows fibrous structure in the middle of the image surrounded by components of the underlying preparation layer. EDX microanalysis shows a sharp $C$ peak with medium and low signals corresponding to the presence of silicon, calcium, aluminium, sulphur, sodium, chloride, magnesium, iron and $\mathrm{Ti}$ from the plaster layer beneath. The absence of phosphorus in the EDX microanalysis suggests that the black carbon was obtained from burnt vegetal matter. The investigation of the plaster sample in the red painted fragment shows fine grains of the preparation layer together with few large quartz grains (Figure 4f). The EDX microanalysis of the sample revealed high concentrations of sulphur and calcium confirming the presence of phases of calcium sulphates as major component in the sample. The preparation layer showed almost same composition of the
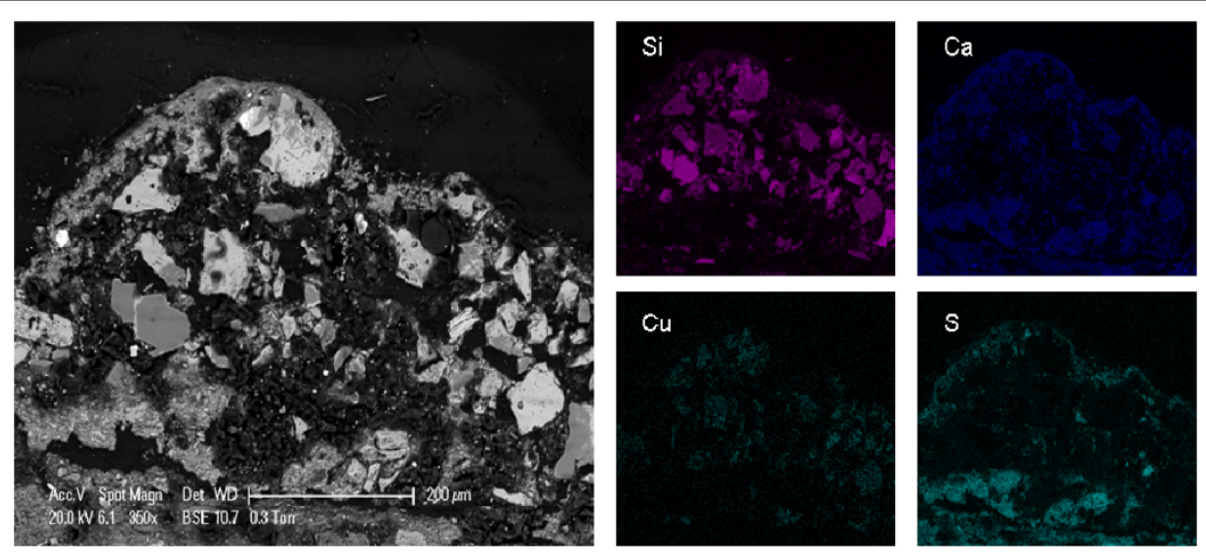

Figure 3 ESEM image (in the backscattered electron mode) obtained on a polished cross-section of the blue paint layer $(350 \times$, scale bar $=200 \mu \mathrm{m})$ and an element distribution map shows silicon, calcium, copper and sulphur are present. 

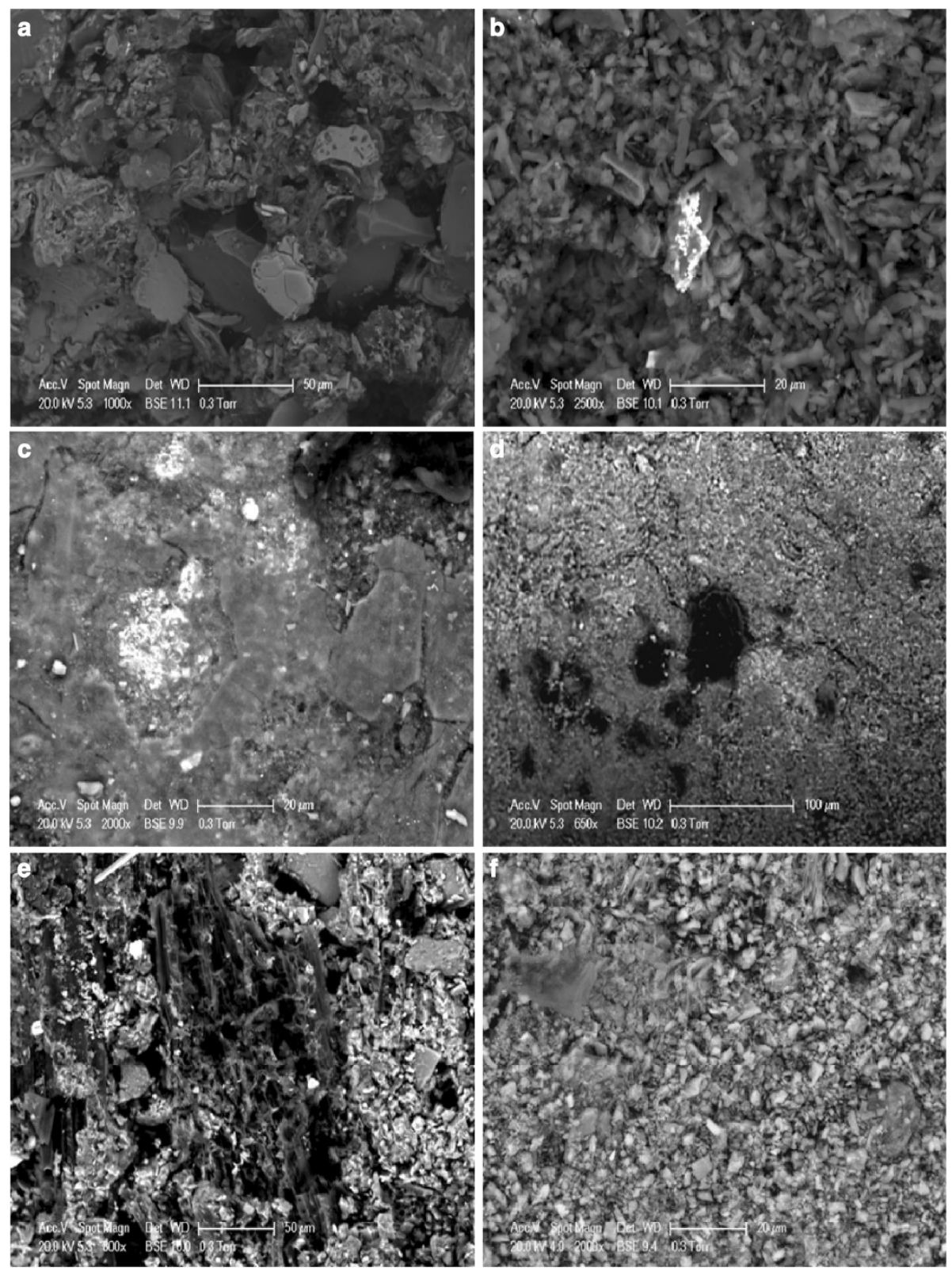

Figure 4 ESEM images obtained on the outer surface of the studied samples, (a): green pigment, bright grey crystals of cuprorivaite are observed $(1000 \times$, scale bar $=50 \mu \mathrm{m})$, (b) iron oxides are observed in the green pigment sample $(2000 \times$, scale bar $=20 \mu \mathrm{m}),(c)$ red pigment sample and the fine grains of haematite are observed $(2000 x$, scale bar $=20 \mu \mathrm{m})$, (d) yellow pigment, fine grained goethite are observed and carbon black are centred in the image $(650 \times$, scale bar $=100 \mu \mathrm{m})$, (e) black pigment, the fibrous structure of a vegetable matter can be observed $(800 x$, scale bar $=50 \mu \mathrm{m})$ and $(f)$ the plaster sample $(2000 x$, scale bar $=20 \mu \mathrm{m})$.

plaster sample since signals of $\mathrm{Ca}, \mathrm{S}$ and $\mathrm{O}$ were also detected (Figure 5). Different proportions of $\mathrm{Si}, \mathrm{Al}$, and $\mathrm{K}$ were also detected.

\section{Results of Raman microscopy}

Figure 6 shows some Raman spectra collected on the pigment and plaster samples. Thanks to the microscopic unit attached to Raman instrument, spectra were recorded on individual grains in the paint layers. The Raman spectrum of the red pigment (Figure 6a) represents typical peaks of haematite $\left(\alpha-\mathrm{Fe}_{2} \mathrm{O}_{3}\right)$ at $226,298,417$ and $614 \mathrm{~cm}^{-1}[39,40]$. Moreover, the strong band at $417 \mathrm{~cm}^{-1}$ indicates a well-crystallised haematite [41]. The band at $147 \mathrm{~cm}^{-1}$ is characteristic of titanium dioxide phase anatase which can be a contaminant in natural iron oxide deposits. A light tone of the red colour was identified as a mixture of haematite based on the bands at 224, 299,414 and $617 \mathrm{~cm}^{-1}$ and gypsum with the characteristic 


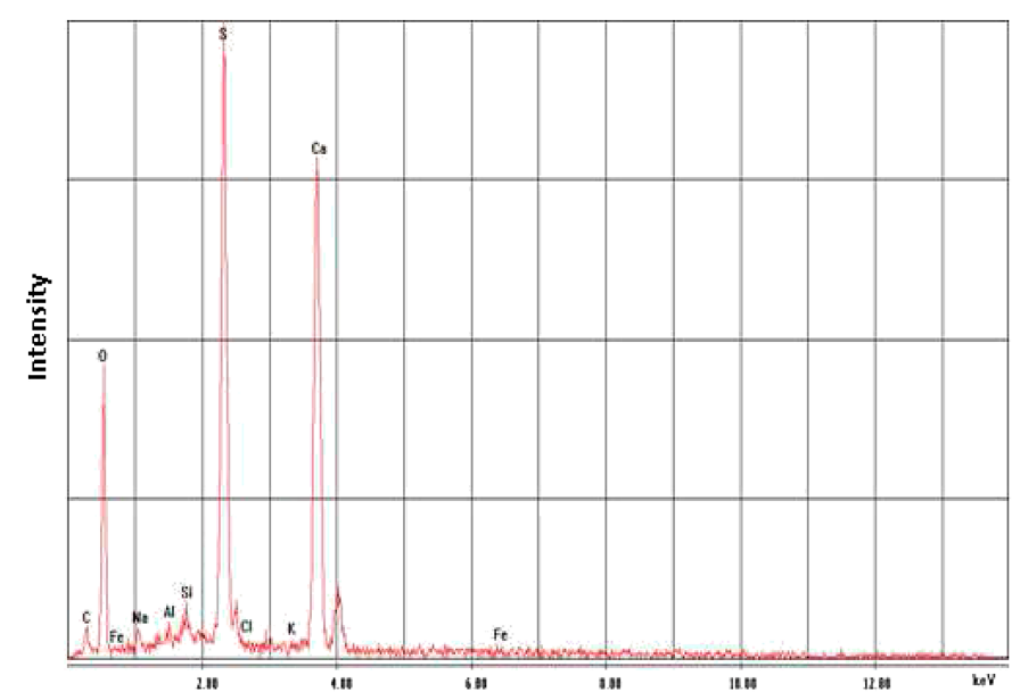

Figure 5 An EDX spectrum obtained on the plaster layer.

$\left[\mathrm{SO}_{4}\right]^{2-}$ stretching mode at $1007 \mathrm{~cm}^{-1}$, and a weak band at $1136 \mathrm{~cm}^{-1}$. The Raman spectrum of the yellow pigment (Figure 6b) shows bands at 395, 305 and $557 \mathrm{~cm}^{-1}$ for goethite $(\alpha-\mathrm{FeOOH})$. The Raman spectrum recorded on black grains in the yellow paint layer (Figure 6c), shows bands at 1383, 1481 and $1578 \mathrm{~cm}^{-1}$ are due to carbon black. The Raman spectrum recorded on the black pigment (Figure 6d) contains two characteristic broad bands for carbon black centred at 1345 and $1583 \mathrm{~cm}^{-1}$ [42]. Raman analyses detected no band at $960 \mathrm{~cm}^{-1}$, the wave number of the stretching of the phosphate ion $\left[\mathrm{PO}_{4}\right]^{3-}$, so the presence of ivory black and bone black one may be excluded. This indicates that carbon was obtained from a vegetable origin. In the case of blue pigment samples, the pigment fluoresced very strongly when it was excited at $785 \mathrm{~nm}$. For this, the identification of the blue pigment samples was based on ESEM-EDX and FTIR-ATR analyses which indeed confirm the presence of cuprorivaite. The Raman spectrum obtained on the preparation layer (Figure 6e) showed the presence gypsum bands at 423, 500,1009 and $1134 \mathrm{~cm}^{-1}$. The plaster layer showed quartz with its characteristic Raman band at $466 \mathrm{~cm}^{-1}$ and the band of gypsum at $1009 \mathrm{~cm}^{-1}$ (Figure 6f).

\section{FTIR-ATR spectra}

Figure 7 shows FTIR-ATR spectrum recorded on the blue pigment sample. The blue pigment sample showed a strong fluorescence using $785 \mathrm{~nm}$ Raman, the FTIR-ATR spectrum recorded on the pigment shows characteristic peaks in the region 1000 and $1050 \mathrm{~cm}^{-1}$ are attributed to $\mathrm{Si}-\mathrm{O}-\mathrm{Si}$ stretching vibrations. In this region, Egyptian blue gives raise to a typical triplet bands, mean ones at 998 and $1045 \mathrm{~cm}^{-1}$ and low intensity bands at $1159 \mathrm{~cm}^{-1}$ [43]. For the green pigment, the following bands arise at:
$3695 \mathrm{~cm}^{-1}$ (Al-O-H str.), 3553 and $3393 \mathrm{~cm}^{-1}$ (O-H stretching); 1106 and $1004 \mathrm{~cm}^{-1}$ (in-plane $\mathrm{Si}-\mathrm{O}$ stretching modes) and $799 \mathrm{~cm}^{-1}$ ( $\mathrm{R}-\mathrm{O}-\mathrm{H}$ bending, where $\mathrm{R}$ is the octahedral ion ${ }^{-} \mathrm{Al}, \mathrm{Fe}^{+2}, \mathrm{Fe}^{+3}, \mathrm{Mg}$ ). These bands are attributed to green earth. The FTIR-ATR spectra recorded on the preparation layer show typical absorption bands of gypsum at 3529, 3401,1682,1620,1104 and $668 \mathrm{~cm}^{-1}$ and the band at $1414 \mathrm{~cm}^{-1}$ is due to calcite. Moreover, the contribution of the quartz is probably corroborated for the appearance of the band at $783 \mathrm{~cm}^{-1}$. The band at $3430 \mathrm{~cm}^{-1}$ is due to free hydroxyl ions of kaolinite (a clay mineral usually associated to ochre pigments), peaks of water $\mathrm{H}-\mathrm{O}-\mathrm{H}$ str., and a broad peak at $3140 \mathrm{~cm}^{-1}$ which was attributed to the peak of hydrated ferric oxide. Bands at $3697,3668,3653$ and $3620 \mathrm{~cm}^{-1}$ indicative of $\mathrm{OH}$ stretching vibrations along with the $\mathrm{OH}$ bending vibrations at 935 and $915 \mathrm{~cm}^{-1}$ suggest that the clay present is kaolinite.

\section{Discussion}

\section{The blue pigment}

The blue pigment was identified as Egyptian blue. The earliest recorded use of this pigment was in the IVth Dynasty (2613-2494 BC) and its use lasted throughout the dynastic period and continued on into the Roman period. For the Ptolemaic-Roman period, we have a description of the manufacture of a blue pigment, which is clearly Egyptian blue frit, given by Vitruvius (at the beginning of the 1st century $\mathrm{BC}$ ). In addition, there is the production debris resulting from the manufacture of Egyptian blue frit at the site of Memphis, near Cairo, that dates to somewhere in the period from 3rd century $\mathrm{BC}$ to 3rd century AD [44]. The optical examination on the blue paint layer showed a think pigmented layer with 

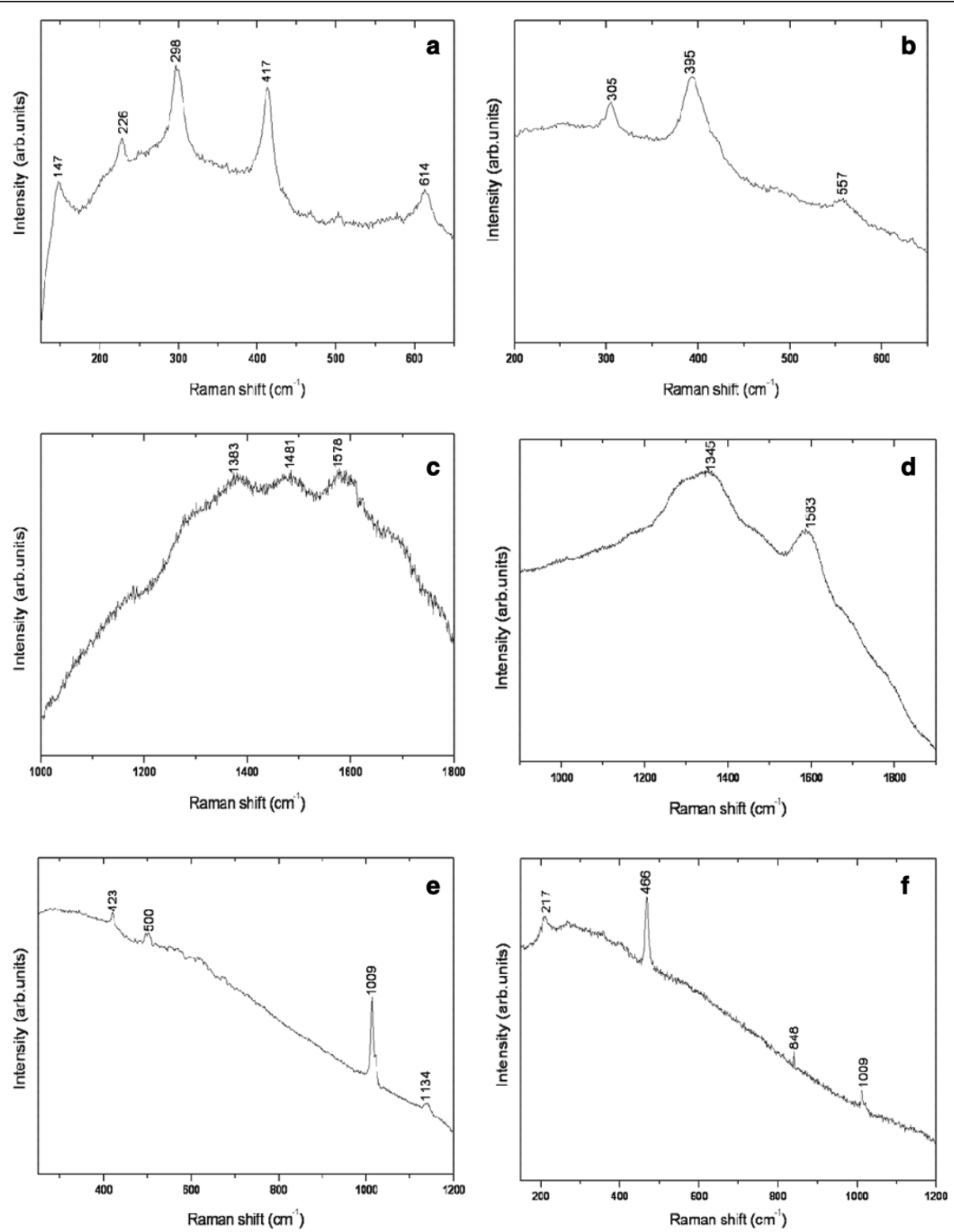

Figure 6 Raman spectra recorded on pigment and plaster samples, (a): red pigment (haematite) (0.5 mW, $5 \mathrm{scans}$ of $20 \mathrm{~s})$, (b): yellow pigment (goethite) $(0.5 \mathrm{~mW}, 5$ scans of $50 \mathrm{~s})$, (c): black grain in yellow pigment (carbon black) $(0.1 \mathrm{~mW}, 10 \mathrm{scans}$ of $20 \mathrm{~s})$, (d): black pigment (carbon black) $(0.1 \mathrm{~mW}, 10$ scans of $20 \mathrm{~s}$ ), (e): preparation layer (gypsum) (1 mW, 10 scans of $20 \mathrm{~s}$ ), (f): plaster layer (quartz + gypsum) $(1 \mathrm{~mW}, 10$ scans of $20 \mathrm{~s})$.

dark blue crystals scattered across a glassy background. For light blue areas, diluted blue is used to describe the colour of fine-textured Egyptian blue that has a large amount of glass formed in its composition, which masks the blue colour and gives it a diluted appearance. Under microscope light, and due to the white binding medium, the colour of such layers is always pale blue. The macroscopic impression however may be more intense blue. In addition, the artist probably wanted a light blue shade for this particular part of the decoration, in which case he has diluted the pigment in more white binder. From the ESEM-EDX analysis, major elements of $\mathrm{Si}, \mathrm{Ca}$ and $\mathrm{Cu}$ were detected and FTIR-ATR analysis confirmed the presence of cuprorivaite. No Raman bands were recorded for the blue pigment samples using our spectrometer (785 nm laser). Egyptian Blue, upon excitation in the visible and NIR, exhibits strong fluorescence emission with a maximum at about $890 \mathrm{~nm}$ [45]. Red and brown grains were observed in the blue paint layers, it is suggested that red ochre was added on purpose to the blue pigment to produce special hues. In his study of blue pigments from the Ptolemaic temple of Hathor at Thebes (decorated in 


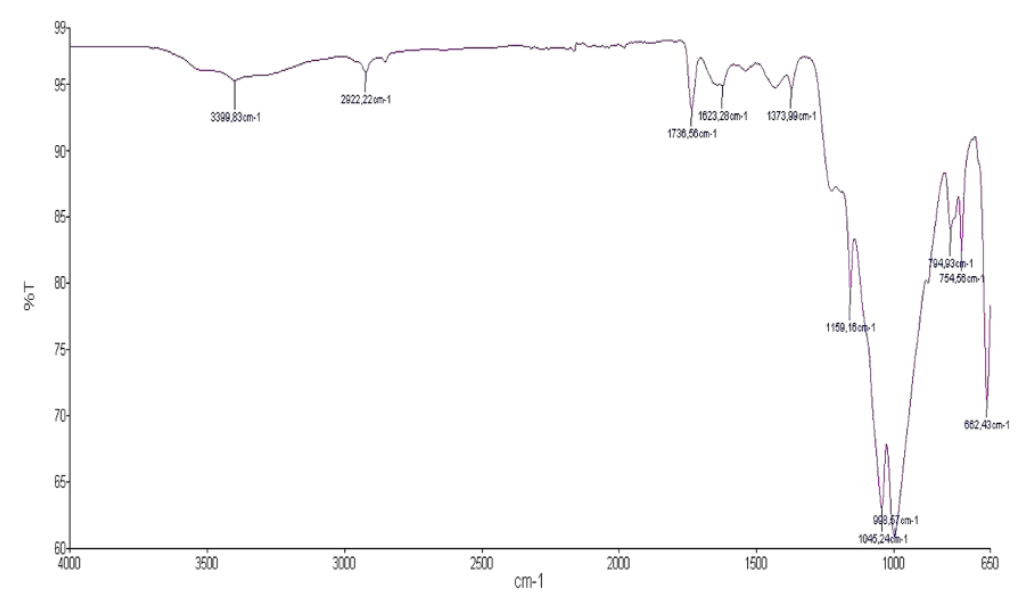

Figure 7 FTIR-ATR spectrum obtained on the blue pigment sample.

the third century by Ptolemy IV and enhanced by Ptolemy VI and also by Ptolemy XI), Marey Mahmoud [38], showed that the blue pigment was identified as Egyptian blue and the micro X-ray fluorescence analysis revealed significant quantities of lead in the glass phase suggesting that a leaded bronze scrap was used to produce the pigment.

\section{The green pigment}

On the basis of ESEM-EDX and FTIR-ATR data, the green pigment was identified as green earth (Terre Verte), also, a green tonality was obtained through a mixture of Egyptian blue and yellow ochre. Such a technique of obtaining green, which appeared sporadically during the XIIth Dynasty (1991-1786 BC), became much more widespread during the Amarna period (1370-1352 BC) [46].

The optical observation under microscope was sufficiently enough to confirm this process since residues of the original blue and yellow pigment grains are clearly observed. Many authors have reported the detection of green earth pigments in Roman wall paintings in Egypt; in their study of the chromatic palette of the Dakke temple at Nubia dating back to the $2^{\text {nd }} \mathrm{BC}$ century Frommold et al. [47], reported that the green pigment was of basic copper chlorides (atacamite, $\mathrm{CuCl}_{2} \mathrm{Cu}(\mathrm{OH})_{2}$ ), but they claimed that they were not able to decide whether it is the originally used pigment or a secondary product of a deterioration process.

\section{The red pigment}

The red pigment was identified as red ochre (haematite). Pigments made from ochre are often discovered as longlasting colourful remains in archaeological contexts. Raman bands recorded on the red pigment showed that a well-crystallised haematite is used. In the Raman spectrum of the pigment, anatase was detected; the most obvious possibility of the detection of this mineral is its simple presence already in the natural geological materials. Both rutile and anatase have been found by other authors in red pigment samples [42]. Red ochre was found combined with carbon black to produce tonalities of dark red and brown.

\section{The yellow pigment}

Pigments made from ochre are often discovered as longlasting colourful remains in archaeological contexts. In the Egyptian wall paintings, ochre pigments were widely used without interruptions from the 5th Dynasty (c. 2494-2345 $\mathrm{BC})$ till the Roman period in Egypt.The yellow pigment was identified as yellow ochre (goethite) (with minor quantities of clay and quartz). Raman bands recorded on the yellow pigment showed that a well-crystallised goethite was used.

\section{The black pigment}

The black pigment was identified as carbon black. Since the characteristic band of $\left[\mathrm{PO}_{4}\right]^{3-}$ was not detected in Raman analyses and no phosphorus was found in the ESEM-EDX analysis, it is possible to exclude the animal origin of the pigment. Black pigments of vegetable origin have generally been made from various kinds of charred plant matter, mostly wood, but also leaves or seeds; the charcoal formed during the charring process is then washed, to remove soluble matter, and finally ground to powder [48]. The analysis of black pigments from the Ptolemaic baths in front of Karnak temples complex, revealed the detection of bone black [49]. Bone black is one of the oldest pigments known to humans, and was originally made by charring animal bones.

\section{Preparation layer and plasters}

From ESEM-EDX, micro-Raman and FTIR-ATR analyses, gypsum was identified as the main component of both the preparation and plaster layers. Many authors 
studied samples from wall paintings in pharaonic temples in Upper Egypt, for example: the temple of Seti I in Abydos, the 19th dynasty, c. 1293-1185 BC) [50], and they have reported that the decorations of these temples were applied in thin layers on a preparation layer consists of gypsum, as it was common in this period of time.

\section{Painting technique}

FTIR-ATR analysis on the pigment samples showed the spectra are consistent with a proteinaceous material (amide II vibration at 1541 and $1578 \mathrm{~cm}^{-1}$ ). The absence of carbonyl bands at c. $1730 \mathrm{~cm}^{-1}$ suggests the presence of a proteinaceous material (probably animal glue). In most of samples, the content of animal glue was not confirmed because the amide I and II bands are masked by the broad bands of calcium sulphate, oxalate and carbonate. Further analysis using gas chromatography mass spectrometry (GC/MS) will be useful to identify the proteins in the sample. From this, we suggest that tempera technique was employed in the decorations of the temple.

\section{Conclusions}

In this study, the complementary use of optical microscopy, Raman microscopy, FTIR-ATR and ESEM-EDX mapping on micro-samples allowed direct identification of the minerals contained in pigment and plaster samples collected from wall paintings of Qasr el-Ghuieta temple, Kharga Oasis, Egypt. The results showed that the pigments used were Egyptian blue (cuprorivaite), red ochre (haematite), yellow ochre (goethite) and carbon black (from a vegetable origin). The green pigment was identified as green earth (Terre Verte), and a green tonality was obtained through a mixture of Egyptian blue and yellow ochre, and in some samples, carbon black was also found. In particular, Raman microscopy was really helpful for identifying individual grains in both the pigment and plaster samples. Several amounts of anatase and carbon black were found in the red and yellow pigments, respectively. The analysis showed that the preparation layer was made of gypsum while the plaster samples consist of quartz, gypsum, calcite and clay minerals. No significant differences were found between the wall decorations of Qasr el-Ghuieta temple, Kharga Oasis, Egypt and those applied in the Pharaonic temples, and their chemical composition and stratigraphy are almost the same. The findings of this study are in accordance with previous analyses of ancient Egyptian pigments, which indicate the continuous use of artificial and natural earth pigments. The results will be used in the conservationrestoration interventions regarding these decorations.

\section{Competing interests}

The author declares that he has no competing interests.

\section{Acknowledgements}

The author is grateful to Mr. Alain Tonetto, Pôle PRATIM, Faculté des Sciences, Aix-Marseille Université for ESEM investigation.

Received: 22 August 2013 Accepted: 6 August 2014

Published: 29 August 2014

\section{References}

1. Gidday L: Egyptian Oases: Bahariya. Farafra and Kharga during Pharaonic Times. Aris and Philips LTD: Dakhla; 1987.

2. Bliss F, Osing J: Oases of Egypt. 1985, 3

3. Cruz-Uribe E: Kharga Oasis, Late Period and Graeco-Roman Sites. In Encyclopedia of the Archaeology of Ancient Egypt. Edited by Bard K. 1999:407.

4. Gebel Ghueita project: Theban Desert Road Survey, Yale Egyptological Institute in Egypt. 2006. available at: http://www.yale.edu/egyptology/ ae_gebel_rear_chamber.htm.

5. Naumann R: Bauwerke der Oase Khargeh. MDAIK 1939, 8:4-7.

6. Silva CL: A Technical Study of the Mural Paintings on the Interior Dome of the Capilla De La Virgen Del Rosario. In Iglesia San José, San Juan, Puerto Rico. University of Pennsylvania, USA: MSc. thesis; 2006.

7. Franquelo ML, Duran A, Herrera LK, de Haro MC J, Perez-Rodriguez L: Comparison between micro-Raman and micro-FTIR spectroscopy techniques for the characterization of pigments from Southern Spain Cultural Heritage. J Mo/ Struct 1999, 924-926:404-412. http://dx.doi.org/ 10.1016/j.molstruc.2008.11.041.

8. Ambers J: Raman analysis of pigments from the Egyptian Old kingdom. J Raman Spectrosc 2004, 35:768-773.

9. David AR, Edwards HGM, Farwell DW, de Faria DLA: Raman spectroscopic analysis of ancient Egyptian pigments. Archaeometry 2001, 43(4):461-473.

10. Edwards HGM, Farwell DW, Newton EM, Rull Perez F, Villar SJ: Raman spectroscopic studies of a 13th century polychrome statue: identification of a'forgotten' pigment. J Raman Spectrosc 2000, 31:407-413.

11. Marey Mahmoud $\mathrm{H}$ : A preliminary investigation of ancient pigments from the mortuary temple of Seti I, El-Qurna (Luxor, Egypt). Mediterranean Archaeology and Archaeometry 2011, 11(1):99-106.

12. Pagés-Camagna S, Colinart S: The Egyptian green pigment: its manufacturing process and links to Egyptian blue. Archaeometry 2003, 45(4):637-658

13. Perardi A, Zoppi A, Castellucci E: Micro-Raman spectroscopy for standard and in situ characterisation of painting materials. J Cult Herit 2000, 1:269-272. http://dx.doi.org/10.1016/S1296-2074(00)00176-X.

14. Borque AG, Ruiz-Moreno S, López-Gil SA: Application of Near Infrared Raman Spectroscopy to the Analysis of Historical Documents. In ICOM-CC Working Group Graphic Documents Interim meeting. Slovenia: Ljubljana: National and University Library; 2004. March 11-12: 73-74.

15. Castro KZ, Pérez-Alonso M, Rodriguez-Laso ZMD, Fernández LA, Madariaga MZJ: On-line FT-Raman and dispersive Raman Spectra database of artists' Materials (e-VISART database). Anal Bioanal Chem 2005, 382:248-258.

16. Marano D, Catalano IM, Monno A: Pigment identification on "Pietà" of Barletta, example of renaissance apulian sculpture: a Raman microscopy study. Spectrochim Acta A 2006, 64:1147-1150. http://dx.doi.org/10.1016/j. saa.2005.12.035.

17. Aliatis I, Bersani D, Campani E, Casoli A, Lottici PP, Mantovan A, Marino I-G, Ospitali F: Green pigments of the Pompeian artists' palette. Spectrochim Acta Part A 2009, 73:532-538. http://dx.doi.org/10.1016/j.saa.2008.11.009.

18. Baraldi P, Baraldi C, Curina R, Tassi L, Zannini P: A micro-Raman archaeometric approach to Roman wall paintings. Vib Spectrosc 2007, 43:420-426. http://dx.doi.org/10.1016/j.vibspec.2006.04.029.

19. Duran A, Perez-Rodriguez JL, Jimenez De Haro MC, Franquelo ML, Robador MD: Analytical study of Roman and Arabic wall paintings in the Patio De Banderas of Reales Alcazares' palace using non-destructive XRD/XRF and complementary techniques. J Archaeo/ Sci 2011, 38(9):2366-2377. http://dx.doi.org/10.1016/j.jas.2011.04.021.

20. Edreira MC, Feliu MJ, Fernández-Lorenzo C, Martín J: Roman wall paintings characterization from Cripta del Museo and Alcazaba in Mérida (Spain): chromatic, energy dispersive X-ray flurescence spectroscopic, X-ray diffraction and Fourier transform infrared spectroscopic analysis. Anal Chim Acta 2001, 434:331-345.

21. Mazzocchin GA, Orsega EF, Baraldi P, Zannini P: Aragonite in Roman wall paintings of the VIIla Regio, Aemilia, and Xa Regio. Venetia Et Histria Ann Chim 2006, 96(7-8):377-387. 
22. Mazzocchin GA, Del Faveroi M, Tasca G: Analysis of pigments from Roman wall paintings in the 'Agro Centuriato' of Julia Concordia (Italy). Ann Chim 2007, 97:905-913.

23. Mazzocchin GA, Vianello A, Minghelli S, Rudello D: Analysis of Roman wall paintings from the Thermae of 'Iulia Concordia'. Archaeometry 2010, 52:644-655.

24. Mirti P, Appolonia L, Casoli A, Ferrari RP, Lurenti E, Amisano Canesi A, Chiari G: Spectrochemical and structural studies on a roman Sample of Egyptian blue. Spectrochim Acta A 1995, 51(3):437-446. http://dx.doi.org/ 10.1016/0584-8539(94)E0108-M

25. Moretto LM, Orsega EF, Mazzocchin GA: Spectroscopic methods for the analysis of celadonite and glauconite in Roman green wall paintings. $J$ Cult Herit 2011, 12(4):384-391. http://dx.doi.org/10.1016/j.culher.2011.04.003

26. Siddall R: Not a day without a line drawn: pigments and painting techniques of roman artists. Proc Roy Microsc Soc 2006, 2:19-31.

27. Villar SEJ, Edwards HGM: An extensive colour palette in Roman villas in Burgos, Northern Spain: a Raman spectroscopic analysis. Anal Bioanal Chem 2005, 382:283-289.

28. Castriota M, Cosco V, Barone T, De Santo G, Carafa P, Cazzanelli E: Micro-Raman characterizations of Pompei's mortars. J Raman Spectrosc 2008, 39:295-301.

29. Duran A, Jimenez De Haro MC, Perez-Rodriguez JL, Franquelo ML, Herrera LK, Justo A: Determination of pigments and binders in Pompeian paintings using synchrotron radiation-high-resolution X-ray power diffraction and conventional spectroscopy-chromatography. Archaeometry 2010 52:286-307

30. Velosa LA, Coroado J, Veiga RM, Rocha F: Characterisation of roman mortars from Conímbriga with respect to their repair. Mater Char 2007, 58(11-12):1208-1216. http://dx.doi.org/10.1016/j.matchar.2007.06.017.

31. Baraldi P, Bonazzi A, Gioedani N, Paccagnella F, Zannini P: Analytical characterization of roman plasters of the 'Domus Farini' in Modena. Archaeometry 2006, 48(3):481-499.

32. Gliozzo E, Cavari F, Damiani D, Memmi I: Pigments and plasters from the Roman settlement of Thamusida (Rabat, Morocco). Archaeometry 2012, 54(2):278-293.

33. Abd El Salam S: Analytical Techniques Used in the Examination of Materials of Wall Paintings from the Ancient Sites of Mustafa Pasha and Anfushi in Alexandria. In The 6th International Conference on Non-Destructive Testing and Microanalysis for the Diagnostic and Conservation of the Cultural and Environmental Heritage, Vol. 1, Rome. Edited by Parisi C, Galiardi S, Parisi GM, Torcinaro G. 1999:446-449.

34. Abd El Salam S: Scientific Study of Græco-Roman Wall Plasters \& Pigments in Alexandria, Egypt. In The 34th International Symposium on Archaeometry, Zaragoza, Spain. Edited by Pérez-Arantegui J. 2004:253-259.

35. Berry M: A study of pigments from a Roman Egyptian shrine. AlCCM Bulletin 1999, 24:1-9.

36. Ali MF: Comparison study of Blue and green pigments from the third intermediate period till the Greek Roman Period. Egypt Egy J Anal Chem 2003, 12:21-30

37. Marey Mahmoud H: Study of the chromatic changes of the ancient pigments in some wall paintings in Egypt and the procedures of conservation. In PhD. Thesis, Postgraduate Interdepartmental Program on: Protection, Conservation \& Restoration of Cultural Monuments. Greece: Faculty of Engineering, Aristotle University of Thessaloniki; 2009.

38. Marey Mahmoud $\mathrm{H}$ : Microanalysis of blue pigments from the Ptolemaic temple of Hathor (Thebes), Upper Egypt: a case study. Surf Interface Anal 2012, 44(9):1271-1278

39. Aibéo CL, Goffin S, Schalm O, van der Snickt G, Laquière N, Eyskens $P$, Janssens $\mathrm{K}$ : Micro-Raman analysis for the identification of pigments from 19th and 20th century paintings. J Raman Spectrosc 2008, 39:1091-1098.

40. Goodall RA, Hall J, Edwards HGM, Sharer RJ, Viel R, Fredericks PM: Raman microprobe analysis of stucco samples from the buildings of Maya classic Copan. J Archaeol Sci 2007, 34(4):666-673. http://dx.doi.org/10.1016/ j.jas.2006.07.008

41. Mazzeo P, Joseph E, Minguzzi V, Grillini G, Baraldi P, Prandstraller D: Scientific investigations of the Tokhung-Ri tomb mural paintings (408 A. D.) of the Koguryo era, Democratic People's Republic of Korea. J Raman Spectrosc 2006, 37:1086-1097.

42. Ospitali F, Smith DC, Lorblanchet M: Preliminary investigations by Raman microscopy of prehistoric pigments in the wall-painted cave at Roucadour, Quercy, France. J Raman Spectrosc 2006, 37:1063-1071.
43. Mazzocchin GA, Rudello D, Bragato C, Agnoli F: A short note on Egyptian blue. J Cult Herit 2004, 5:129-133. http://dx.doi.org/10.1016/j. culher.2003.06.004

44. Hatton GH, Shortland AJ, Tite MS: The production technology of Egyptian blue and green frits from second millennium BC Egypt and Mesopotamia. J Archaeo Sci 2008, 35(6):1591-1604. http://dx.doi.org/ 10.1016/j.jas.2007.11.008.

45. Westlake P, Siozos P, Philippidis A, Apostolaki C, Derham B, Terlix A, Perdikatsis $V$, Jones RE, Anglos D: Studying pigments on painted plaster in Minoan, Roman and Early Byzantine Crete a multi-analytical technique approach. Anal Bioanal Chem 2012, 402(4):1413-1432. http://dx.doi.org/ 10.1016/j.jas.2013.09.020.

46. Ragai J: Colour: its significance and production in Ancient Egypt. Endeavour, New Series 1986, 10(2):74-79.

47. Frommold C, Bremser W, Reiche I, Reinholz U, Seidlmayer S, Weise H-P: An Archaeometric Application Of External Beam PIXE: Colour Reconstruction Of An Egyptian Temple Relief. In Proceedings of the 10th International Conference on Particle Induced X-ray Emission and its Analytical Applications, Portorož, Slovenia, June 4-8; 2004:307.1-307.4.

48. Goffer Z: Archaeological Chemistry. Secondth edition. Hoboken, New Jersey: John Wiley \& Sons, Inc; 2007:71-72.

49. Marey Mahmoud H, Ali MF, Pavlidou E, Kantiranis N, EL-Badry A: Characterization of plasters from Ptolemaic baths:new excavations near the Karnak temple complex, Upper Egypt. Archaeometry 2011, 53(4):693-706

50. Pavlidou E, Marey Mahmoud H, Roumeli E, Zorba F, Paraskevopoulos KM, Ali MF: Identifying Pigments in the Temple of Seti I in Abydos (Egypt). In The 14th European Microscopy Congress, Vol. 2: Materials Science, September 1-5. Edited by Richter S, Schwedt A. Aachen, Germany: Springer-Verlag Berlin Heidelberg; 2008:829-830.

doi:10.1186/s40494-014-0018-x

Cite this article as: Mahmoud: Investigations by Raman microscopy, ESEM and FTIR-ATR of wall paintings from Qasr el-Ghuieta temple, Kharga Oasis, Egypt. Heritage Science 2014 2:18

\section{Publish with ChemistryCentral and every scientist can read your work free of charge \\ "Open access provides opportunities to our colleagues in other parts of the globe, by allowing anyone to view the content free of charge." W. Jeffery Hurst, The Hershey Company. \\ - available free of charge to the entire scientific community \\ - peer reviewed and published immediately upon acceptance \\ - cited in PubMed and archived on PubMed Central \\ - yours - you keep the copyright \\ Submit your manuscript here: \\ http://www.chemistrycentral.com/manuscript/<smiles>c1ccccc1</smiles> \\ Chemistry Central}

